\title{
The Nutritional Basis for Food Selection by Ungulates
}

THOMAS A. HANLEY

\begin{abstract}
A conceptual framework is outlined for understanding the reasons why ungulates select the kinds of foods that they do. It consists of four morphological parameters: (1) body size and (2) type of digestive system (cecal or ruminant) determine the overall time-energy constraints within which the ungulate may forage selectively; (3) rumino-reticular volume to body weight ratio determines the type of food the ruminant is most efficient in processing; and (4) mouth size determines the ability of the ungulate to harvest selectively plant parts of individuals. Principal premises are the following: (1) large ungulates and cecal digestors are more limited by time than are small ungulates and ruminant digestors; (2) high rumino-reticular volume to body weight ratio is an adaptation to exploiting thick cell-walled, high cellulose diets (i.e., graminoids); and (3) low rumino-reticular volume to body weight ratio is an adaptation to exploiting thin but lignified cell-walled diets (i.e., browse).
\end{abstract}

The composition of diets selected by wild and domestic ungulates has long been of interest to range and wildlife ecologists. Numerous tabulations of diet composition data are available in the literature. However, diet composition data alone are not satisfactory for explaining the reasons for observed diet differences between animal species. A knowledge of the reasons why ungulates select the foods that they do is necessary for an understanding of the forage needs of range animals and the underlying basis of competitive interactions among them.

The theory of optimal foraging strategies has provided a means of examining resource partitioning in consumer communities. It is a theory based on the assumption that natural selection acts on phenotypic variation within populations with the result that greatest genetic fitness is conferred to individuals which feed most efficiently (i.e., prefer an optimal diet). The primary objective of the theory is to specify the complex of behavior and morphology which best suits a particular animal to a particular environment (Schoener 1971). A prerequisite of devising tests of this hypothesis is that the optimal diet can be defined. The problem of determining an optimal diet under a given set of circumstances consists of three major parts: (1) choosing the most appropriate currency to be maximized (e.g., energy); (2) determining the most appropriate constraints imposed on the animal; and (3) solving for the optimum solution to the cost-benefit functions (Shoener 1971). This has most commonly resulted in the following algorithm for determining the optimal diet (defined as the diet which maximizes the net rate of energy or mass intake in a fine-grain situation): potential food items arc ranked by their net values, i.e., ratio of food value (however defined) to handling time; abundances of food types and total time for foraging are taken into account; and the optimal diet is then determined by beginning with the food type of highest net value and adding food types in rank order to the diet as long as the

\footnotetext{
Author was with the College of Forest Resources University of Washington, Seattle, Wash., at the time of the research. His current address is U.S.D.A., Forest Service, Pacific Northwest Forest and Range Experiment Station, Forestry Sciences Laboratory; P.O. Box 909, Juneau, Alaska 99802.

Manuscript received July $31,1980$.
}

net rate of food intake is increased by the inclusion of the additional food type in the diet (Pyke et al. 1977). Optimal diets determined in this manner have three properties in common: (1) whether or not a food type is included in the optimal diet is independent of the abundance of that food type and depends only on the abundance of higher quality food types; (2) as the abundance of a preferred food type increases, less preferred food types drop out of the optimal diet; and (3) any food type within the optimal diet is either eaten whenever encountered or passed by whenever encountered (unless differential nut rient const raints also are considered; e.g., Pulliam 1975) (Pyke et al. 1977). This theory has centered on the strategic aspects of feeding and seldom has dealt with the tactical aspects. Although numerous papers have dealt with optimal foraging strategies (Emlen 1966, 1968; MacArthur and Pianka 1966; Levins 1968; Levins and MacArthur 1969; Schoener 1969, 1971; Tullock 1971; Rapport 1971; Cody 1974; Pulliam 1974, 1975; Katz 1974; Westoby 1974; Estabrook and Dunham 1976; Ellis et al. 1976; Pyke et al. 1977; Hughes 1979; Stenseth and Hansson 1979; Sih 1979), the applicability of this theory to ungulate food selection remains unsatisfactory (Westoby 1978). The existing theory largely has developed around data on food selection by carnivores, granivores, and frugivores, all of which prey upon food items occurring as discrete "packages." Large, generalist herbivores, on the other hand, select food items from a chemically heterogeneous spectrum, and what constitutes an individual food item is of ten not evident. Chemical description of the food item is itself a difficult task, each plant being highly variable, depending on plant part (Gwynne and Bell 1968, Halls and Epps 1969, Blair et al. 1977), plant vigor (Cook et al. 1962), habitat (Halls and Epps 1969), phenology (Laycock and Price 1970), and intraspecific variation (Garten 1978). Furthermore, different species of plants differ greatly in their content of specific nutrients (Cowan et al. 1970) as well as toxins and digestion inhibitors (Levin 1976, Feeny 1976, Rhoades and Cates 1976, Jung 1977, Laycock 1978), the so-called secondary plant compounds. A large, generalist herbivore therefore must select a diet within the constraints of minimal levels of specific plant nutrients (Halls 1970, Westoby 1974) as well as maximal levels of specific secondary plant compounds (Freeland and Janzen 1974).

To apply existing optimal foraging models to ungulate food selection it must be assumed that large, generalist herbivores can rank potential food items according to their net value. Furthermore, the animal must be able to keep track of the constantly changing values of the food items and adjust their ranked vahues as a function of differing phenologies and habitats. The foraging ungulate would have to detect the values of individual species while consuming continuous multi-species meals. The ruminant herbivore would be confronted with the additional complication of differing nut ritional value of a food item as a consequence of other food items in the rumen (Church 1975). The tactical difficulties of such a scenario have been addressed by Westoby (1978), who concluded that the underlying assumptions of current optimal 
foraging models were not met satisfactorily by the case of the large generalist herbivore. Even if this were not so, the difficulties of quantifying the neccssary parameters are great. However, although we are not yet able to predict the "optimal diet" in quantitative, taxonomic terms for a given ungulate, it would appear feasible to predict the general type of diet that an ungulate, given a choice, will select. Ruminant nutritionists, and more recently ecologists, have developed a body of knowledge and a conceptual framework for understanding food selection and food resource partitioning in ungulate communities. The purpose of this paper is to review this framework and to identify some implications for competition theory and habitat management.

\section{Forage Selection Framework}

The framework consists of four morphological parameters: (1) body size, (2) type of digestive system (cecal or ruminant), (3) rumino-reticular volume to body weight ratio, and (4) mouth size. The hypothesis is that a knowledge of the values of these parameters is sufficient for prediction of the types of foods a given ungulate is most efficient in exploiting; or conversely, knowledge about the types of food available in a given habitat is sufficient to predict values of these morphological parameters for the type of ungulate(s) most efficient in exploiting them. Briefly, the idea is that body weight and type of digcstive system determine the overall time-energy constraints within which the ungulate must secure its food. Rumino-reticular volume determines the type (characteristics of) food items the ruminant is most efficient in processing. Mouth size determines the degree of selectivity that is mechanically possible for the forager to exhibit and the time and energy costs of selectively foraging on specific plant parts or individuals.

\section{Body Size}

The food requirements of mammals increase with increasing body weight as a result of increasing costs of maintenance and production (Moen 1973). The increase is not linear, however (Cordova et al. 1978). Kleiber (1961) estimated that the basal metabolic rate (kcal/day) of mammals is approximately seventy times the three-fourth power of their body weight (in $\mathrm{kg}$ ). Thus although larger mammals require more nutrients per day than smaller mammals do, their relative requirements (per unit weight of body tissue) are lower. The relative value of large body weight in the food selection process is dependent upon the availability of nutritious forage (Case 1979). A larger mammal, requiring a greater absolute quantity of nutrients during a day, has less time per nutrient unit to spend selectively foraging than does a smaller mammal with a lower absolute requirement. The larger mammal has a lower relative requirement, however, and therefore can meet its nutritional needs with relatively lower quality forage. Thus, Bell $(1969,1971)$ has generalized that where forage quantity is limiting, small body size is advantageous; where forage quality is limiting, large body size is advantageous. The "limiting" nature of the forage quantity or quality is determined by the time-energy constraints upon the forager. A smaller forager has relatively more time to spend foraging (and therefore can be more selective in what it chooses to eat); but the benefits of spending more time foraging must outweigh the costs. Energy cost for the foraging ruminant is a direct function of the time spent foraging (Osuji 1974).

\section{Digestive System}

Although the cellular contents of plants are high digestible, the plant cell wall poses digestive difficulties for herbivores (Van Soest 1965a, 1965b; Smith et al. 1971, 1972). Two major types of digestive systems have evolved in ungulates to enable them to digest plant cell walls by anaerobic fermentation and to subsist on relatively high fiber diets. These are the ruminant and the cecal digestive systems (Janis 1976). The ruminant system has evolved in the Artiodactyla and is found in most species of this group. All species of the Perissodactyla are cecal digestors. The actual process of fermentation is very similar in the rumen and the cecum (Janis 1976); and the rate of digestion of a cotton string in the cecum of a horse is comparable to that in the rumen of a cow (Alexander
952). However, horses are only about $70 \%$ as efficient as cattle and sheep are in digesting cellulose (Heinlein et al. 1966, VanderNoot and Gilbreath 1970, Janis 1976).

The ruminant digestive system has two principal advantages. One is that the regurgitated "cud" can be chewed repeatedly, thereby grinding the food to a smaller particle size. The other is that food is digested by microbes before entering the true stomach (abomasum). Plant material is digested by bacteria and protozoa in the rumen and converted to microbial tissue or waste products which are absorbed there or ultimately digested by the ruminant in the abomasum. This has advantages in terms of nitrogen cycling and digestive efficiency (Houpt 1959, Mugerwa and Conrad 1971, Nolan and Leng 1972, Robbins et al. 1974). In the cecal digestive system, microbial fermentation takes place after the food has passed through the stomach, and very little microbial protein can be recycled (Janis 1976). The principal disadvantage of the ruminant digestive system is that in order for food to pass from the rumen into the rest of the digestive tract, it must be broken down to a relatively small particle size (Hungate 1966). Very fibrous forages, therefore, limit the rate of food passage through the gastrointestinal tract of the ruminant and restrict consumption of additional forage (Fontenot and Blaser 1965, Van Soest 1965a, Weston 1966, Ammann et al. 1973). The cecal digestor, however, is not limited by such a constraint (Janis 1976). It may be less efficient at digesting the fibrous cell walls of plants but can pass much more plant material through its system daily. The ruminant must be a more selective forager than the cecal digestor must be; but being a more efficient digestor, it requires a lower absolute quantity of forage. It therefore has been generalized that where forage quantity is limiting, a ruminant digestive system is advantageous; whereas where forage quality is limiting, a cecal digestive system is advantageous (Bell 1969, 1971; Janis 1976). This is analogous to the relative value of body size and therefore is similarly important in determining the overall time-energy constraints on the foraging ungulate.

\section{Rumino-reticular Volume}

The most basic subdivision of plant material is between cellular contents and cell walls (Van Soest 1965b, 1967; Van Soest and Wine 1967). The cellular contents are highly digestible, generally about $98 \%$ digestible (Goering and Van Soest 1970), but the cell walls are much less so. Plant cell walls are composed primarily of cellulose, hemicellulose, and lignin. Cellulose is digestible by rumen and cecal microbes; hemicellulose may or may not be digestible, depending on the type of hemicellulose; and lignin is generally considered nondigestible (Goering and Van Soest 1970; Smith et al. 1971, 1972). Plant species and plant parts differ in their proportions of cellular contents, cellulose, hemicellulose, and lignin. Rapidly growing plant tissue and the leaves and new stem production of shrubs and forbs generally have relatively thin cell walls and a high proportion of cellular contents (Short 1971, Segelquist et al. 1972, Cook 1972, Albersheim 1975, Blair et al. 1977, Milchunas et al. 1978:8, Short 1981). Mature grasses and woody tissue, however, generally have thick cell walls, composed primarily of cellulose in grasses, and relatively high in lignin in shrubs (Short 1971, Johnston et al. 1968, Segelquist et al. 1972, Cook 1972, Albersheim 1975, Blair et al. 1977, Milchunas et al. 1978:8, Short 1981).

Plant cellular contents, therefore, are the most valuable food source for herbivores, but their relative availability is seasonal and/or dependent upon the degree of selectivity that the herbivore can exercise. Cellulose is potentially a high energy food source and is relatively abundant where grasses comprise a substantial proportion of the vegetation. Cellulose digestion, however, is a time dependent process with a sigmoidal response curve (Hungate 1966, Torgerson and Pfander 1971), presumably due to the increased rate of digestion as long fibers are broken into many shorter fibers by enzyme action.

Cellulose digestion and the rate of food passage through the rumen are closely related a spects of ruminant digestion (Nagy et al. 
1969). In order to benefit from a high cellulose diet, food must be retained in the rumen for a sufficient time to digest the cellulose. For an animal with a relatively small rumen, rumen fill is reached in a relatively short time during feeding (Purser and Moir 1966), and consequently voluntary intake would be greatly restricted on a high cellulose diet. An animal with a large rumen, however, would have a relatively slow rumen turnover rate, thereby keeping a given food particle in the rumen for a longer time period despite a relatively high rate of food consumption. Voluntary intake would not be as greatly restricted as for the animal with the small rumen. Thus, a large rumen is advantageous for subsisting on a high cellulose (i.e., graminoid) diet (Nagy et al. 1969).

The proportion of lignin in a forage is an important factor affecting the nutritional quality of a forage. Lignin is not only virtually nondigestible, but also interferes with cellulose digestion (Head 1961; Smith et al. 1971, 1972; Robbins and Moen 1975), presumably by decreasing the amount of cellulose accessible for bacterial action. It therefore would be disadvantageous for an animal with a large rumen to consume a diet relatively high in lignin (e.g., browse). A slow rumen turnover rate in such a case would greatly reduce the efficiency of rumen fermentation (Hungate 1966, 1975). On the other hand, a high rumen turnover rate would be advantageous for an animal with a diet relatively high in lignin. Plant cellular contents are digested very rapidly (Van Soest 1965a; Hungate 1966, 1975), and the rapid passage of the lignified cell walls would be beneficial. For a ruminant to subsist on such a diet, however, it must be able to obtain a diet relatively high in cellular contents and not waste time and energy processing lignin and cellulose.

The rumino-reticular volume to body weight ratio $(1 / \mathrm{kg})$ of a ruminant therefore determines the type of food the ruminant is most efficient in digesting. High rumino-reticular volume to body weight ratio is an adaptation to a high cellulose content diet, typically a diet consisting primarily of grasses. Low ruminoreticular volume to body weight ratio is an adaptation to a high cellular content and/or high lignin diet, typically a diet consisting primarily of young grasses, forbs, and browse (Nagy et al. 1969, Hofmann and Stewart 1972). Rumino-reticular volume to body weight ratios of North American ungulates typically range from about 0.10 (e.g. deer, Odocoileus spp.) to 0.25 (e.g. domestic sheep, Ovis aries, and cattle, Bos spp. (See Hanley and Hanley (1982), for an analysis of diet selection by these species).

Hofmann (1973) studied the diet composition and stomach morphology of 26 species of African ruminants. On the basis of data collected from 263 animals, he classified African ruminants into three major groups based on stomach structure and food selection: (1) concentrate selectors, (2) bulk and roughage eaters, and (3) intermediate feeders. The concentrate selectors had very small rumens and diets of fruit, forb foliage, and tree and shrub foliage. The bulk and roughage eaters had very large rumens and diets of grasses. The intermediate feeders had intermediate size rumens and diets of grasses, forbs, and tree and shrub foliage. In studies of digestive efficiency, Maloiy et al. (1970) found that red deer (Cervus elaphus), with a smaller rumino-reticular volume to body weight ratio than sheep (Ovis aries), were less efficient cellulose digestors than sheep. On the other hand, white-tailed deer (Odocoileus virginianus), with a smaller rumino-reticular volume to body weight ratio than cattle (Bos spp.), have been reported to be more efficient than cattle in utilizing browse forages (Short 1963). Similar results for deer and sheep have been reported by Longhurst et al. (1968). Differences in rumen volume and turnover rate have been suggested as being important factors in resource partitioning in ungulate communities (Hungate et al. 1959, Milchunas et al. 1978).

\section{Mouth Size}

The degree of selectivity that can be exercised by a large herbivore, within its time-energy constraints, is determined largely by mouth size. Animals with small mouths are more capable of being selective of plant parts than animals with la rge mouths are (Meyer et al. 1957, McClymont 1967, Jarman 1974). Mouth size and bod size, however, seem to be highly correlated, presumably because $c$ the overall time-energy const raints on forage selectivity. Data fror fistulated animals show that sheep obtain a higher quality diet tha cattle do by selecting higher quality plant parts when both specis have access to the same forage (Cook et al. 1963, Church 1975:54 Empirical observations of differential effects of grazing antelof bitterbrush (Purshia tridentata) by cattle, sheep, and deer als demonstrate the importance of mouth size. Whereas grazing b cattle results in a club-shaped or mushroom-shaped, heavil hedged shrub, grazing by sheep or deer results in a tall, straggl growth form. The difference is due to the consumption of ol woody tissue along with the current annual growth by cattl compared to the selective removal of only the current annu: growth by sheep and deer (Hormay 1943). Observations of tam Rocky Mountain elk (Cervus elaphus) and mule deer (Odocoileu hemionus) foraging in the same habitats indicated an average bit size (oven-dry weight) of about 0.4 to 0.6 grams for elk (Collins c al. 1978) compared to 0.1 grams for deer (Deschamp et al. 1979 Whereas deer were highly selective when browsing shrubs an removed only the leaves and current annual growth, elk, with the larger mouths, removed both old and new growth with each bit (W.B. Collins and J.A. Deschamp, personal correspondence).

\section{Relationships between Parameters}

Several relationships between parameters have been mentione already. In terms of the time-energy constraints imposed on th foraging ungulate, large body size and cecal digestive system hav similar effects. Mouth size probably is influenced largely by th time-energy constraints.

The relationships between rumen turnover time, fermentatic rate, and increasing relative metabolic requirements with decrea ing body size have prompted the suggestion hy some autho (Hungate et al. 1959, Nagy et al. 1969, Hoppe 1977) that sma ruminants meet their relatively high metabolic requirements $t$ having a small rumen volume, short turnover time, high ferment: tion rate, and highly selective diet. While this may be true in mar cases, notable exceptions to the rule demonstrate that body si: and rumen volume are not necessarily dependent upon or another. Rather, the relationship is dependent upon the nutrition characteristics of the forage resource that is exploited. The elan antelope (Taurotragus oryx), for example, is a very large (400-8C $\mathrm{kg}$ ) African ruminant with a relatively small rumen (rumin reticular volume to body weight ratio of about 0.110 ) Hofman 1973:267). It is "best suited for rapidly fermenting plant materia (Hofmann 1973:267) and is a selective forager, primarily eatir dicotyledonous forage (Hofmann 1973). The domestic sheep $c$ the other hand, is a relatively small (about $50 \mathrm{~kg}$ ) ruminant with very large rumen (rumino-reticular volume to body weight ratio r about 0.250 ). It has a relatively long rumen turnover time (Malo: et al. 1968), and eats a diet consisting of a substantial proportion ( grasses (Olsen and Hansen 1977, Stuth and Win ward 1977, Hanle and Hanley 1982). The domestic sheep is very well adapted $t$ producing on poor quality rangeland-its small body size an ruminant digestive system minimize the time-energy constrain and provide a relatively large amount of time to forage selectivel (Lofgreen et al. 1957; Arnold 1960, 1962); the large rumen volum enables it to exploit the relatively abundant sources of fermentab carbohydrates (Maloiy et al. 1970); and the small mouth siz enables it to be highly selective of the plant parts and individua taken (Arnold 1960, 1962; Cook et al. 1963; Eadie 1969; Churc 1975:54). The combination of small body size and large rume volume, however, has an obvious disadvantage in terms of escap from predators.

The ability to forage selectively (determined by the time-energ constraints and mouth size) is very important when browse is bein eaten. Whereas leaves and current annual growth of browse specis may be about $65 \%$ cell solubles and $10 \%$ lignin, older twigs may $t$ only $30 \%$ cell solubles and $20 \%$ lignin (Blair et al. 1977). The abilit to harvest selectively the leaves and current annual growth withol 
also harvesting the older twigs therefore is important in determining the relative value of a browse forage to an herbivore. Such ability has been mentioned frequently for small-mouthed ruminants such as sheep, pronghorn, and deer (Cook and Harris 1950; Meyer et al. 1957; Weir and Torell 1959; Arnold 1960, 1962a, 1962b, 1964; McClymont 1967; Eadie 1969; Healy 1971; Short 1977), but seldom mentioned for large-mouthed ungulates such as cattle or horses. Rather, cattle do not appear to be capable of such a fine degree of selectivity, as evidenced by their browsing effects on the growth form of antelope bitterbrush (Hormay 1943). Rocky Mountain elk are smaller than either cattle or horses yet also apparently are incapable of harvesting only leaves and current annual growth from shrubs that are routinely browsed in this manner by mule deer (W.B. Collins and J.A. Deschamp, personal correspondence).

The relatively high degree of intraspecific variation in forage quality within browse species is another important aspect of the relationship between forage selectivity and the desirability of browse forages. Large differences in palatability have commonly been observed within browse species (Smith 1950; Oh et al. 1967; Nagy and Tengerdy 1967, 1968; Longhurst et al. 1968; Nagy and Regelin 1977) but are seldom reported for graminoids. Existing evidence is that these differences are due to the presence of plant volatile oils (Nagy et al. 1964, Nagy and Regelin 1977), which are recognizable by smell or taste (Longhurst et al. 1968, Nagy and Regelin 1977). If a foraging ungulate must take the time to smell or taste each individual of a particular species to determine its volatile oil content, then certainly herbivores that are more restricted by time-energy constraints (large ruminants and cecal digestors) would be more negatively influenced by the presence of volatile oils in some plant individuals than herbivores with more relaxed timeenergy const raints would be. The large herbivore should "view" the plant species more in relation to its mean nutritional value; whereas the small herbivore may take the time necessary to seek out and consume only the most nutritious individuals.

The foregoing discussion has emphasized the forage selection, harvesting, and processing aspects of the ungulate herbivore. There are advantages and disadvantages associated with the possible values of each of the four major parameters: body size, type of digestive system, rumino-reticular volume, and mouth size. The optimal combination of values, however, is dependent not only upon the nature of the forage resource, but also upon the constraints of climate (Moen 1973, Western 1975) and predation (Geist 1974), as well as the potential for social organization to modify these factors (Jarman 1974, Geist 1974). The wide array of existing species of ungulates represents the numerous possible solutions to this optimization problem.

This is not meant to imply that other forage nutritional parameters or secondary plant compounds are not important factors in ungulate forage selection. It is suggested that these are of secondary importance, however, and are more important at a finer grain of resolution beyond the framework presented here. The roles of these factors are probably those of minimum nutrient constraints (Westoby 1974) and maximum secondary plant compound constraints (Freeland and Janzen 1974) in determining the species composition of the optimal diet.

\section{Competition and Habitat Management}

Although the present framework for understanding forage selection by ungulates is not sufficient for prediction of the species composition of optimal diets, it does provide much more insight into competition and resource partitioning in ungulate communities than has been provided by current models of optimal foraging strategies. It should provide a useful basis for understanding food selection in other herbivore communities as well, where cecal digestion and coprophagy are important nutritional aspects (see Janis 1976). Food resource partitioning, however, is only one dimension of niche separation (Schoener 1974). An understanding of the temporal and spatial components of habitat selection will further refine and extend the applicability of the present framework.

Dietary overlap is not sufficient evidence for exploitative competition (Colwell and Futuyuma 1971, Pianka 1976). For example, the present framework suggests that systems analogous to the facilitative grazing systems described for the Serengeti Plains of East Africa (Gwynne and Bell 1968; Bell 1969, 1971; McNaughton 1976) may operate in range livestock-wildlife relationships in North America. Early greening spring grasses are important components of mule deer diets in the Rocky Mountain and intermountain regions of North America (Willms and McLean 1978, Carpenter et al. 1979). While heavy livestock use at that time may result in exploitative competition for this forage resource, light or moderate use, particularly by cattle, conceivably may be beneficial to deer due to the compensatory growth responses by the grazed plants and a prolongation of the time period of active leaf growth (McNaughton 1979).

Where exploitative competition for the forage resource does exist, the present framework may provide insight into expected equilibrial outcomes. The appropriate model for competition between cattle and deer, for example, is most likely along the lines of Schoener's (1974) model for exploitative competition where each species has exclusive resources. Competition between sheep and deer, however, may be more similar to Miller's (1964, 1967) "included niche" model. The equilibrial outcomes of these two models can be entirely different. Whereas competition in Schoener's model always results in a stable node equilibrium, with the population levels of both species depressed, competition in Miller's model can yield either a stable node or competitive exclusion, depending on whether or not individuals of the narrow-niched species (deer) are sufficiently better than those of the broad-niched species (sheep) at exploiting the overlapping resources and whether those resources are sufficiently abundant to permit coexistence.

The present framework is also useful for predicting the consequences of management actions aimed at habitat improvement. The revitalization of decadent antelope bitterbrush ranges, for example, is a frequent objective in the management of the intermountain rangeland of North America. If bitterbrush decadence has resulted from excessive use by cattle, then the present framework suggests that simple reductions in the number of cattle permitted to graze the range will not solve the bitterbrush problem unless sufficient high quality grass forage is made available so that bitterbrush drops out of the optimal diet for cattle. If bitterbrush remains in the optimal diet, then use of bitterbrush by cattle will increase with any improvement in bitterbrush growth form. In such a situation, a rest-rotation grazing management system probably would be more effective in yielding the desired results.

An understanding of the forage needs of wild and domestic ungulates and the competitive relationships among them is important for wise management of these renewable resources. The brief review outlined here highlights only some of the research that has focused on this need.

\section{Literature Cited}

Albersheim, P. 1975. The walls of growing plant cells. Sci. Amer. 232:80-95. Alexander, F. 1952. Some functions of the large intestine in the horse. Quart. J. Exp. Physiol. 37:205-214.

Ammann, A.P., R.L. Cowan, C.I. Mothershed, and B.R. Baumgardt. 1973. Dry matter and energy intake in relation to digestibility in whitetailed deer. J. Wildl. Manage. 37:195-201.

Arnold, G.W. 1960a. The effect of the quantity and quality of pasture available to sheep on their grazing behaviour. Aust. J. Agr. Res. 11:10341043.

Arnold, G.W. 1960b. Selective grazing by sheep of two forage species at different stages of growth. Aust. J. Agr. Res. 11:1026-1033.

Arnold, G.W. 1962a. Factors within plant associations affecting the behaviour and performance of grazing animals. p. 133-154. In: D.J. Crisp, editor. Grazing in terrestrial and marine environments. Symp. Brit. Ecol. Soc. (Bangor). Blackwell Sci. Publ., Oxford.

Arnold, G.W. 1962b. Effects of pasture maturity on the diet of sheep. Aust. J. Agr. Res. 13:701-706. 
Arnold, G.W.1964. Some principles in the investigation of selective grazing Proc. Aust. Soc. Anim. Prod. 5:258-271.

Bell, R.H.V. 1969. The use of the herb layer by grazing ungulates in the Serengeti. p. 111-123 In: A. Watson, editor. Animal populations in relation to their food resources. Symp. Brit. Ecol. Soc. (Aberdeen). Blackwell Sci. Pub., Oxford and Edinburg.

Bell, R.H.V. 1971. A grazing ecosystem in the Serengeti. Sci. Amer. 225(I):86-93.

Blair, R.M., H.L. Short, and E.A. Epps, Jr. 1977. Seasonal nutrient yield and digestibility of deer forage from a young pine plantation. J. Wildl. Manage. 41:667-676.

Carpenter, L.H., O.C. Wallmo, and R.B. Gill. 1979. Forage diversity and dietary selection by wintering mule deer. J. Range Manage. 32:226-229.

Case, T.J. 1979. Optimal body size and an animal's diet. Acta Biotheor. 28:54-69.

Church, D.C. 1975. Digestive physiology and nutrition of ruminants. Vol. 1. Digestive physiology, second edition. O\&B Books, Corvallis, Ore. 350

Cody, M.L. 1974. Optimization in ecology. Science 183:1156-1164.

Collins, W.B., P.J. Urness, and D.D. Austin. 1978. Elk diets and activities on different lodgepole pine habitat segments. J. Wildl. Manage. 42:799. 810.

Colwell, R.K., and D.J. Futuyma. 1971. On the measurement of niche breadth and overlap. Ecology 52:567-576.

Cook, C.W. 1972. Comparative nutritive value of forbs, grasses, and shrubs. p. 303-310. In: C.M. McKell, J.P. Blaisdell, and J.R. Goodin, editors. Wildlife shrubs-their biology and utilization. U.S. Dep. Agr. Forest Serv. Gen. Tech. Rep. INT-1.

Cook, C.W., K. Taylor, and L.E. Harris. 1962. The effect of range condition and intensity of grazing upon daily intake and nutritive value of the diet on desert ranges. J. Range Manage. 15:1-6.

Cook, C.W., J.T. Blake, and J.W. Call. 1963. Use of esophageal-fistula cannulae for collecting forage samples from both sheep and cattle grazing in common. J. Anim. Sci. 22:579-581.

Cook, C.W., and L.E. Harris. 1950. The nutritive content of the grazing sheep's diet on summer and winter ranges in Utah. Bull. Utah Agr. Exp. Sta. No. $342.66 \mathrm{p}$.

Cordova, R.J., J.D. Wallace, and R.D. Pieper. 1978. Forage intake by grazing livestock: a review. J. Range Manage. 31:430-438.

Cowan, R.L., J.S. Jordan, J.L. Grimes, and J.D. Gill. 1970. Comparative nutritive values of forage species. p. 48-56 In: Range and wild life habitat evaluation, a research symposium. U.S. Dep. Agr. Forest Serv. Misc. Pub. 1147

Deschamp, J.A., P.J. Urness, and D.D. Austin. 1979. Summer diets of mule deer from lodgepole pine habitats. J. Wildl. Manage. 43:154-161.

Eadie, J. 1969. Sheep production and pastoral resources. p. 7-24 In: A. Watson, editor. Animal populations in relation to their food resources. Symp. Brit. Ecol. Soc. (Aberdeen). Blackwell Sci. Pub., Oxford and Edinburgh.

Ellis, J.E., J.A. Wiens, C.F. Rodell, and J.C. Anway. 1976. A conceptual model of diet selection as an ecosystem process. J. Theor. Biol. 60:93-108.

Emlen, J.M. 1966. The role of time and energy in food preference. Amer. Natur. 100:611-617.

Emlen, J.M. 1968. Optimal choice in animals. Amer. Natur. 102:385-390.

Estabrook, G.F., and A.E. Dunham. 1976. Optimal diet as a function of absolute abundance, relative abundance, and relative value of available prey. Amer. Natur. 110:401-413.

Feeny, P. 1976. Plant apparency and chemical defense. Recent Adv. Phytochem. 10:1-40.

Fontenot, J.P., and RE. Blaser. 1965. Symposium on factors influencing the voluntary intake of herbage by ruminants: selection and intake by grazing animals. J. Anim. Sci. 24:1202-1208.

Freeland, W.J., and D.H. Janzen. 1974. Strategies in herbivory by mammals: the role of plant secondary compounds. Amer. Natur. 108:269-289.

Garten, C.T., Jr. 1978. Multivariate perspectives on the ecology of plant mineral element composition. Amer. Natur. 112:533-544.

Geist, V. 1974. On the relationship of social evolution and ecology in ungulates. Amer. Zool. 14:205-220.

Goering, H.R., and P.J. Van Soest. 1970. Forage fiber a nalysis. U.S. Dep. Agr., Agr. Res. Serv., Agr. Handbook No. 379. 20 p.

Gwynne, M.D., and R.H.V.Bell. 1968. Selection of vegetation components by grazing ungulates in the Serengeti National Park. Nature, London 220:390-393.

Halls, L.K. 1970. Nutrient requirements of livestock and game. p. 10-18 In: Range and wildlife habitat evalution, a research symposium. U.S. Dep. Agr. Forest Serv. Misc. Pub. 1147.

Halls, L.K., and E.A. Epps, Jr. 1969. Browse quality influenced by tree overstory in the South. J. Wildl. Manage. 33:1028-1031
Hanley, T.A., and K.A. Hanley. 1982. Food resource partitioning by sympatric ungulates on Great Basin rangeland J. Range Manage. 35:152158.

Head, M.J. 1961. Cellulose digestibility in the rumen. p. 263-271. In: D. Lewis, editor. Digestive physiology and nutrition of the ruminant. Buttersworth, London.

Healy, W.M. 1971. Forage preferences of tame deer in a northwest Pennsylvania clear-cutting. J. Wildl. Manage. 35:717-723.

Heinlein, E.F.W., R.D. Holdren, and R.M. Yoon. 1966. Comparative responses of horses and sheep to different physical forms of alfalfa hay. $J$. Anim. Sci. 25:740-743.

Hofmann, R.R. 1973. The ruminant stomach: stomach structure and feeding habits of East African game ruminants. East African Monographs in Biology, Vol. 2. East African Literature Bureau, Nairobi, Kenya. 354 p.

Hofmann, R.R., and D.R.M. Stewart. 1972. Grazer or browser: a classification based on the stomach-structure and feeding habits of east African ruminants. Mammalia 36:226-240.

Hoppe, P.P. 1977. Rumen fermentation and body weight in African ruminants. Internat. Cong. Game. Biol. (Atlanta) 13:141-150.

Hormay, A.L. 1943. Bitterbrush in California. U.S. Dep. Agr. Forest Serv., California Forest and Range Exp. Sta. Res. Note No. 34. 13 p.

Houpt, T.R. 1959. Utilization of blood urea in ruminants. Amer. J. Physiol. 197:115-120.

Hughes, R.N. 1979. Optimal diets under the energy maximization premise: the effects of recognition time and learning. Amer. Natur. 113:209-221.

Hungate, R.E. 1966. The rumen and its microbes. Academic Press, New York and London. $533 \mathrm{p}$.

Hungate, R.E. 1975. The rumen microbial ecosystem. Annu. Rev. Ecol. Syst. 6:39-66.

Hungate, R.E., G.D. Phillips, A. McGregor, D.P. Hungate, and H.K. Buechner. 1959. Microbial fermentation in certain animals. Science 130:1192-1194.

Janis, C. 1976. The evolutionary strategy of the Equidae and the origins of rumen and cecal digestion. Evolution 30:757-774.

Jarman, P.J. 1974. The social organization of antelope in relation to their ecology. Behaviour 48(3-4):215-267.

Johnston, A., L.M. Bezeau, and S. Smoliak. 1968. Chemical composition and in vitro digestibility of alpine tundra plants. J. Wildl. Manage. 32:773-777.

Jung, H.G. 1977. Responses of mammalian herbivores to secondary plant compounds. Biologist 59:123-136.

Katz, P.L. 1974. A long-term approach to foraging optimization. Amer. Natur. 108:443-457.

Kleiber, M. 1961. The fire of life. Wiley, New York. 453 p.

Laycock, W.A. 1978. Coevolution of poisonous plants and large herbivores on rangelands. J. Range Manage. 31:335-342.

Laycock, W.A., and D.A. Price. 1970. Factors influencing forage quality: environmental influences on nutritional value of forage plants. p. 37-47 In: Range and wildlife habitat evaluation, a research symposium. U.S. Dep. Agr. Forest Serv. Misc. Pub. 1147.

Levin, D.A. 1976. The chemical defenses of plants to pathogens and herbivores. Annu. Rev. Ecol. Syst. 7:121-159.

Levins, R. 1968. Evolution in changing environments. Princeton University Press, Princeton. 120 p.

Levins, R., and R.H. MacArthur. 1969. An hypothesis to explain the incidence of monophagy. Ecology 50:910-911.

Lofgreen, G.P., J.H. Meyer, and J.L. Hull. 1957. Behaviour patterns of sheep and cattle being fed pasture or silage. J. Anim. Sci. 16:773-780.

Longhurst, W.M., M.K. Oh, M.B. Jones, and R.E. Kepner. 1968. A basis for the palatability of deer forage plants. No. Amer. Wildl. Nat. Res. Conf. Trans. 33:181-192.

MacArthur, R.H., and E.R. Pianka. 1966. On the optimal use of a patchy habitat. Amer. Natur. 100:603-609.

Maloiy, G.M.O., R.N.B. Kay, and E.D. Goodall. 1968. Studies on the physiology of digestion and metabolism of the red deer (Cervus elaphus). Symp. Zool. Soc. London 21:101-108.

Maloiy, G.M.O., .N.B. Kay, E.D. Goodall, and J.H. Topps. 1970. Digestion and nitrogen metabolism in sheep and red deer given large or small amounts of water and protein. Brit. J. Nutr. 24:843-855.

McClymont, G.L. 1967. Selectivity and intake in the grazing ruminant. p. 129-137. In: C.R. Code, editor. Handbook of physiology, sec. 6: alimentary canal, Vol. 1. American Physiological Society, Washington, D.C.

McNaughton, S.J. 1976. Serengeti migratory wildebeest: facilitation of energy flow by grazing. Science. 191:92-94

McNaughton, S.J. 1979. Grazing as an optimization process: grassungulate relationships in the Serengeti. Amer. Natur. 113:691-703.

Meyer, J.H., G.P. Lofgreen, and J.H. Hull. 1957. Selective grazing by 
sheep and cattle. J. Anim. Sci. 16:766-772

Milchunas, D.G., M.I. Dyer, O.C. Wallmo, and D.E. Johnson. 1978. In-vivo/in-vitro relationships of Colorado mule deer forages. Colorado Div. Wildl. Spec. Rep. No. 43.44 p.

Miller, R.S. 1964. Ecology and distribution of pocket gophers (Geomyidae) in Coloradu. Eculugy 45:256-272.

Miller, R.S. 1967. Pattern and process in competition. Adv. Ecol. Res. 4:1-74.

Moen, A.N. 1973. Wildlife ecology, an analytical approach. Freeman, San Francisco. $458 \mathrm{p}$.

Mugerwa, J.S., and H.R. Conrad. 1971. Relationship of dietary nonprotein nitrogen to urea kinetics in dairy cows. J. Nutr. 101:1331-1342.

Nagy, J.G., H. Steinhoff, and G.M. Ward. 1964. Effects of essential oils of sagebrush on deer rumen microbial function. J. Wildl. Manage. 28:785790.

Nagy, J.G., and R.P. Tengerdy. 1967. Antibacterial action of essential oils of Artemisia as an ecological factor. 1. Antibacterial action of the volatile oils of Artemisia tridentata and Artemisia nova on aerobic bacteria. Appl. Microbiol. 15:819-821.

Nagy, J.G., and R.P. Tengerdy. 1968. Antibacterial action of essential oils of Artemisia as an ecological factor. 11. Antibacterial action of the volatile oils of Artemisia tridentata (big sagebrush) on bacteria from the rumen of mule deer. Appl. Microbiol. 16:441-444.

Nagy, J.G., T. Hakonson, and K.L. Knox. 1969. Effects of quality on food intake in deer. No. Amer. Wildl. Nat. Res. Conf. Trans. 34:146-154.

Nagy, J.G., and W.L. Regelin. 1977. Influence of plant volatile oils on food selection by animals. Internat. Congr. Game Biol. (Atlanta) 13:225-230.

Nolan, J.F., and R.A. Leng. 1972. Dynamic aspects of ammonia and urea metabolism in sheep. Brit. J. Nutr. 27:177-194.

Oh, H.K., T. Sakai, M.B. Jones, and W.M. Longhurst. 1967. Effect of essential oils isolated from Douglas-fir needles upon sheep and deer rumen microbial activity. Appl. Microbiol. 15:777-784.

Olsen, F.W., and R.M. Hansen. 1977. Food relations of wild free-roaming horses to livestock and big game, Red Desert, Wyoming. J. Range Manage. 30:17-20.

Osuji, P.0. 1974. The physiology of eating and the energy expenditure of the ruminant at pasture. J. Range Manage. 27:437-443.

Pianka, E.R. 1976. Competition and niche theory. p. 114-141. In: R.M. May, editor. Theoretical ecology: principles and applications. Saunders, Philadelphia and Toronto.

Pulliam, H.R. 1974. On the theory of optimal diets. Amer. Natur. 108:5974.

Pulliam, H.R. 1975. Diet optimization with nutrient constraints. Amer. Natur. 109-765-768.

Purser, D.B., and R.J. Moir. 1966. Rumen volume as a factor involved in individual sheep differences. J. Anim. Sci. 25:509-515.

Pyke, G.H., H.R. Pulliam, and E.L. Charnov. 1977. Optimal foraging: a selective review of theory and tests. Quart. Rev. Biol. 52:137-154.

Rapport, D.J. 1971. An optimization model of food selection. Amer. Natur. 105:575-587.

Rhoades, D.F., and R.G. Cates. 1976. Toward a general theory of plant antiherbivore chemistry. Recent Adv. Phytochem. 10:168-213.

Robbins, C.T., and A.N. Moen. 1975. Composition and digestibility of several deciduous browses in the Northeast. J. Wildl. Manage. 39:337341.

Robbins, C.T., R.L. Prior, A.N. Moen, and W.J. Visek. 1974. Nitrogen metabolism of white-tailed deer. J. Anim. Sci. 38:186-191.

Schoener, T.W. 1969. Models of optimal size for solitary predators. Amer. Natur. 103:227-313.

Schoener, T.W. 1971. Theory of feeding strategies. Annu. Rev. Ecol. Syst. 2:369-404.
Schoener, T.W. 1974. Competition and the form of habitat shift. Theor. Pop. Biol. 6:265-307.

Segelquist, C.A., H.L. Short, F.D. Ward, and R.G. Leonard. 1972. Quality of some winter deer forages in the Arkansas Ozarks. J. Wildl. Manage. 36:174-177.

Short, H.L. 1963. Rumen fermentations and energy relationships in whitetailed deer. J. Wildl. Manage. 27:184-195.

Short, H.L. 1971. Forage digestibility and diet of deer on southern upland range. J. Wildl. Manage. 35:698-706.

Short, H.L. 1977. Food habits of mule deer in a semidesert grass-shrub habitat. J. Wildl. Manage. 30:206-209.

Short, H.L. 1981. Nutrition and metabolism. In: Wallmo, O.C. (ed.) Mule and black-tailed deer of North America. p. 99-127. Univ. Nebr. Press. Lincoln and London.

Sih, A. 1979. Optimal diet: the relative importance of the parameters. Amer. Natur. 113:460-463.

Smith, A.D. 1950. Inquiries into differential consumption of juniper by mule deer. Utah Fish and Game Bull. No. 9. 4 p.

Smith, L.W., H.K. Goering, and C.H. Gordon. 1972 Relationships of forage compositions with rates of cell wall digestion and indigestibility of cell walls. J. Dairy Sci. 55:1140-1147.

Smith, L.W., H.K. Goering, D.R. Waldo, and C.H. Gordon. 1971. In vitro digestion rate of forage cell wall components. J. Dairy Sci. 54:71-76.

Stenseth, N.C., and L. Hansson. 1979. Optimal food selection: a graphic model. Amer. Natur. 113:373-398.

Stuth, J.W., and A.H. Winward. 1977. Livestock-deer relations in the lodgepole pine-pumice region of central Oregon. J. Range Manage. 30:110-116.

Torgerson, O., and W.H. Pfander. 1971. Cellulose digestibility and chemical composition of Missouri deer foods. J. Wildl. Manage. 35:221-231.

Tullock, G. 1971. The coal tit as a careful shopper. Amer. Natur. 105:77-80.

VanderNoot, G.W., and E.C. Gilbreath. 1970. Comparative digestibility of components of forage by geldings and steers. J. Anim. Sci, 31:351-355.

Van Soest, P.J. 1965a. Symposium on factors influencing the voluntary intake of herbage by ruminants: voluntary intake in relation to chemical composition and digestibility. J. Anim. Sci. 24:834-843.

Van Soest, P.J. 1965b. Non-nutritive residues: a system of analysis for the replacement of crude fiber. Ass. Off. Agr. Chem. J. 49:546-551.

Van Soest, P.J. 1967. Development of comprehensive system of feed analysis and its application to forages. J. Anim. Sci. 26:I 19-128.

Van Soest, P.J., and R.H. Wine. 1967. Use of detergents in the analysis of fibrous feeds. IV. Determination of plant cell-wall constituents. Ass. Off. Anal. Chem. J. 50:50-55.

Weir, W.K., and D.T. Torell. 1959. Selective grazing by sheep as shown by a comparison of the chemical composition of range and pasture forage obtained by hand clipping and that collected by esophagael fistulated sheep. J. Anim. Sci. 18:641-649.

Western, D. 1975. Water availability and its influence on the structure and dynamics of a savannah large mammal community. E. Afr. Wildl. J. 13:265-286.

Westoby, M. 1974. An a nalysis of diet selection by large generalist herbivores. Amer. Natur. 108:290-304.

Westoby, M. 1978. What are the biological bases of varied diets? Amer. Natur. 112:627-631.

Weston, R.H. 1966. Factors limiting the intake of feed by sheep. I. The significance of palatability, the capacity of the alimentary tract to handle digesta, and the supply of glucogenic substrate. Aust. J. Agr. Res. 17:939-954

Willms, W., and A. McLean. 1978. Spring forage selection by tame mule deer on big sagebrush range, British Columbia. J. Range Manage. 31:192-199. 